\title{
Variovorax soli sp. nov., isolated from greenhouse soil
}

Correspondence

Soon-Wo Kwon

swkwon@rda.go.kr

\author{
Byung-Yong Kim, ${ }^{1}$ Hang-Yeon Weon, ${ }^{2}$ Seung-Hee Yoo, ${ }^{1}$ \\ Seon-Young Lee, ${ }^{1}$ Soon-Wo Kwon, ${ }^{1}$ Seung-Joo Go ${ }^{1}$ \\ and Erko Stackebrandt ${ }^{3}$
}

\footnotetext{
1,2Korean Agricultural Culture Collection (KACC), Microbial Genetics Division, National Institute of Agricultural Biotechnology ${ }^{1}$ and Applied Microbiology Division, National Institute of Agricultural Science and Technology2, Rural Development Administration, Suwon 441-707, Republic of Korea

${ }^{3}$ Deutsche Sammlung von Mikroorganismen und Zellkulturen $\mathrm{GmbH}$, Mascheroder Weg 1b, D-38124 Braunschweig, Germany
}

\begin{abstract}
A Gram-negative, rod-shaped, non-spore-forming bacterium, strain $\mathrm{GH} 9-3^{\top}$, isolated from greenhouse soil, was investigated in a polyphasic study. The novel organism grew at $10-35{ }^{\circ} \mathrm{C}$, $0-3 \% \mathrm{NaCl}$ and $\mathrm{pH} 5-9$. It had ubiquinone $8(\mathrm{Q}-8)$ as the predominant isoprenoid quinone and possessed $\mathrm{C}_{16: 0}$, summed feature $3, \mathrm{C}_{17: 0}$ cyclo and $\mathrm{C}_{18: 1} \omega 7 \mathrm{c}$ as the major fatty acids (together representing $87 \cdot 4 \%$ of the total). The DNA G $+\mathrm{C}$ content was $67 \cdot 1 \mathrm{~mol} \%$. $16 \mathrm{~S}$ rRNA gene sequence analysis of strain $\mathrm{GH} 9-3^{\top}$ showed that it grouped within the Variovorax cluster, with highest sequence similarities to Variovorax paradoxus IAM $12373^{\top}(98.3 \%)$ and Variovorax dokdonensis DS-43 ${ }^{\top}$ (98.0\%). DNA-DNA hybridization values between strain $\mathrm{GH} 9-3^{\top}$ and $V$. paradoxus DSM $30034^{\top}$ and $V$. dokdonensis DS $-43^{\top}$ were 38 and $29 \%$, respectively. Based on phenotypic, chemotaxonomic and phylogenetic features, it is proposed that strain $\mathrm{GH} 9-3^{\top}$ represents a novel species of the genus Variovorax with the name Variovorax soli sp. nov. The type strain is $\mathrm{GH} 9-3^{\top}\left(=\operatorname{KACC} 11579^{\top}=\mathrm{DSM} 18216^{\top}\right)$.
\end{abstract}

The genus Variovorax, which was created to accommodate Alcaligenes paradoxus (Willems et al., 1991), is affiliated to the family Comamonadaceae of the Betaproteobacteria (Anzai et al., 2000). The type species of this genus is Variovorax paradoxus, and another species in the genus, Variovorax dokdonensis, was recently proposed from a soil isolate (Yoon et al., 2006).

Strain GH9- $3^{\mathrm{T}}$ was isolated from greenhouse soil cultivated with lettuce (Lactuca sativa L.) in Wanju region, Korea. The soil sample was serially diluted with $0 \cdot 85 \% \mathrm{NaCl}(\mathrm{w} / \mathrm{v})$, spread on R2A (Reasoner \& Geldreich, 1985) and incubated at $30{ }^{\circ} \mathrm{C}$ for 3 days. The isolate was maintained on R2A and stored at $-80{ }^{\circ} \mathrm{C}$ with $15 \%$ glycerol (v/v).

The morphological, physiological and biochemical characteristics of strain $\mathrm{GH} 9-3^{\mathrm{T}}$ were investigated using routine cultivation on $\mathrm{R} 2 \mathrm{~A}$ medium at $30^{\circ} \mathrm{C}$. Gram reaction and cell morphology were observed by light microscopy and negatively stained whole cells were viewed by transmission electron microscopy. Catalase and oxidase activity and hydrolysis of casein, carboxymethylcellulose, DNA, gelatin,

The GenBank/EMBL/DDBJ accession number for the $16 \mathrm{~S}$ rRNA gene sequence of strain $\mathrm{GH}-3^{\mathrm{T}}$ is $\mathrm{DQ} 432053$. tyrosine and starch were determined as described by Smibert \& Krieg (1994). Growth was assessed at 5, 10, 20, 25, 30, 35, 40 and $45^{\circ} \mathrm{C}$, at $\mathrm{pH} 4,5,6,7,8,9$ and 10 , and at $0,1,3,5$ and $7 \% \mathrm{NaCl}$. Growth and biochemical tests were also carried out using API 20NE, API ID 32 GN and API ZYM commercial kits (bioMérieux).

PCR amplification of the 16S rRNA gene was carried out as described previously (Kwon et al., 2003). Sequencing was performed using an automated DNA sequencer model 3100 (Applied Biosystems). The 16S rRNA gene sequences were aligned using CLUSTAL W (Thompson et al., 1994). A phylogenetic analysis was performed using MEGA version 3.1 (Kumar et al., 2004). Distances (using distance options according to the Kimura two-parameter model) and clustering using the neighbour-joining method and maximum-parsimony (Kumar et al., 2004) were determined using bootstrap values based on 1000 replicates.

Isoprenoid quinones were analysed by HPLC as described previously (Groth et al., 1996). Whole-cell fatty acids were analysed according to the standard protocol of the MIDI/ Hewlett Packard Microbial Identification System (Sasser, 1990) after cultivation on R2A for 2 days at $30^{\circ} \mathrm{C}$. Determination of DNA $\mathrm{G}+\mathrm{C}$ content was according to 
the method of Mesbah et al. (1989) using a reversed-phase column (Supelcosil LC-18-S; Supelco).

DNA-DNA hybridization was carried out as described by Seldin \& Dubnau (1985). Probe labelling was conducted using a non-radioactive DIG High Prime DNA Labelling and Detection Starter kit II (Roche Molecular Biochemicals). Hybridized DNA was visualized using a DIG luminescent detection kit (Roche).

Table 1. Phenotypic comparison of strain $\mathrm{GH} 9-3^{\top}$ and the type strains of Variovorax species

Strains: 1, GH9-3 ${ }^{\mathrm{T}}$ (V. soli sp. nov.); 2, V. paradoxus DSM $30034^{\mathrm{T}}$; 3, V. dokdonensis DS- $43^{\mathrm{T}}$. Data were obtained in this study unless indicated. All three strains were positive for alkaline phosphatase, esterase (C4), esterase lipase (C8), leucine arylamidase and naphthol-AS-BI-phosphohydrolase and negative for starch hydrolysis, anaerobic growth with nitrate, indole production, glucose fermentation, arginine dihydrolase, aesculin hydrolysis, gelatin hydrolysis, $\beta$-galactosidase, lipase (C14), cystine arylamidase, trypsin, $\alpha$-chymotrypsin, $\alpha$-galactosidase, $\beta$-galactosidase, $\beta$-glucuronidase, $N$-acetyl- $\beta$-glucosaminidase, $\alpha$-mannosidase and $\alpha$-fucosidase. All three strains assimilated D-glucose, L-arabinose, potassium gluconate, adipic acid, malic acid, suberic acid, lactic acid, 3-hydroxybenzoic acid, L-histidine, 3-hydroxybutyric acid and 4-hydroxybenzoic acid and did not assimilate $\mathrm{N}$-acetylglucosamine, D-maltose, capric acid, trisodium citrate, L-rhamnose, inositol, sucrose, itaconic acid, glycogen, L-serine, salicin, D-melibiose or L-fucose. +, Positive; - , negative; w, weakly positive.

\begin{tabular}{|c|c|c|c|}
\hline Characteristic & 1 & 2 & 3 \\
\hline Flagella & $1-3$ & Peritrichous ${ }^{a_{\star}}$ & Peritrichous $^{b}$ \\
\hline DNA G $+\mathrm{C}$ content $(\mathrm{mol} \%)$ & $67 \cdot 1$ & $67 \cdot 0^{a}$ & $66 \cdot 0^{b}$ \\
\hline Nitrate reduction & + & + & - \\
\hline Urease & - & - & + \\
\hline Valine arylamidase & - & $\mathrm{W}$ & - \\
\hline Acid phosphatase & + & - & + \\
\hline$\alpha$-Glucosidase & - & + & $\mathrm{W}$ \\
\hline \multicolumn{4}{|l|}{ Assimilation of: } \\
\hline D-Mannose & - & + & - \\
\hline D-Mannitol & + & + & - \\
\hline Phenylacetic acid & + & - & - \\
\hline D-Ribose & - & + & - \\
\hline Sodium malonate & - & + & - \\
\hline Sodium acetate & - & + & - \\
\hline L-Alanine & - & - & + \\
\hline Potassium 5-ketogluconate & - & + & - \\
\hline D-Sorbitol & + & + & - \\
\hline Propionic acid & + & - & + \\
\hline Valeric acid & + & - & + \\
\hline Potassium 2-ketogluconate & + & - & + \\
\hline L-Proline & - & + & + \\
\hline
\end{tabular}

${ }^{\star}$ Data taken from: $a$, Willems et al. (1991); b, Yoon et al. (2006).
Colonies of strain $\mathrm{GH} 9-3^{\mathrm{T}}$ were irregular and yellow in colour on R2A medium. Cells were non-spore-forming, motile, short rods, approximately $0.5-0.7 \times 1 \cdot 0-1.5 \mu \mathrm{m}$. The strain grew on R2A, nutrient agar (Difco), trypticase soy agar (Difco) and MacConkey agar (Difco). A phenotypic comparison of strain $\mathrm{GH} 9-3^{\mathrm{T}}$ and the other Variovorax species is shown in Table 1.

The major isoprenoid quinone of GH9-3 ${ }^{\mathrm{T}}$ was ubiquinone 8 (Q-8). Strain GH9-3 ${ }^{\mathrm{T}}$ contained high proportions of $\mathrm{C}_{16: 0}$ $(33 \cdot 2 \%)$, summed feature $3\left(29 \cdot 3 \%\right.$, comprising $\mathrm{C}_{15: 0}$ iso 2-OH and/or $\left.\mathrm{C}_{16: 1} \omega 7 c\right), \mathrm{C}_{17: 0}$ cyclo (15.9\%) and $\mathrm{C}_{18: 1} \omega 7 c$ $(9 \cdot 0 \%)$ (Table 2). No significant differences in fatty acid profiles were found from other Variovorax species. The DNA G $+C$ content was $67 \cdot 1 \mathrm{~mol} \%$.

The almost complete 16S rRNA gene sequence of strain GH9- $3^{\mathrm{T}}$ (1457 nt) was used in the phylogenetic analysis. Isolate GH9- $3^{\mathrm{T}}$ showed highest sequence similarities to $V$. paradoxus IAM $12373^{\mathrm{T}}(98 \cdot 3 \%)$ and $V$. dokdonensis DS- $43^{\mathrm{T}}$ $(98.0 \%)$. Sequence similarities to the other species shown in Fig. 1 were below $97 \%$. According to the phylogenetic tree, strain GH9- $3^{\mathrm{T}}$ formed a robust cluster $(90 \%$ bootstrap values) with $V$.paradoxus and $V$. dokdonensis, indicating that this strain is a member of the genus Variovorax. DNA-DNA hybridizations between strain $\mathrm{GH} 9-3^{\mathrm{T}}$ and $V$. paradoxus DSM $30034^{\mathrm{T}}$ and $V$. dokdonensis DS- $43^{\mathrm{T}}$ yielded relatedness values of 38 and $29 \%$, respectively. These values are well below the threshold of $70 \%$ suggested for species delineation (Stackebrandt \& Goebel, 1994), indicating that strain GH9$3^{\mathrm{T}}$ represents a genomic species separate from $V$. paradoxus and $V$. dokdonensis. On the basis of these results, strain GH9$3^{\mathrm{T}}$ represents a novel species of the genus Variovorax, for which the name Variovorax soli sp. nov. is proposed.

Table 2. Cellular fatty acid compositions (\%) of strain GHO $-3^{\top}$ and the type strains of Variovorax species

Strains: 1, GH9-3 ${ }^{\mathrm{T}}$ (V. soli sp. nov.); 2, $V$. paradoxus DSM $30034^{\mathrm{T}}$; 3, V. dokdonensis DS- $43^{\mathrm{T}}$. -, Less than $1 \%$ or not detected.

\begin{tabular}{|lccc|}
\hline Fatty acid & $\mathbf{1}$ & $\mathbf{2}$ & $\mathbf{3}$ \\
\hline $\mathrm{C}_{10: 0} 3-\mathrm{OH}$ & $5 \cdot 1$ & $3 \cdot 7$ & $3 \cdot 2$ \\
$\mathrm{C}_{12: 0}$ & $3 \cdot 2$ & $3 \cdot 7$ & $4 \cdot 0$ \\
$\mathrm{C}_{12: 0} 3-\mathrm{OH}$ & - & - & $3 \cdot 3$ \\
$\mathrm{C}_{14: 0}$ & - & - & $1 \cdot 0$ \\
$\mathrm{C}_{14: 0} 2-\mathrm{OH}$ & - & $2 \cdot 7$ & - \\
$\mathrm{C}_{15: 0}$ & - & - & $1 \cdot 8$ \\
$\mathrm{C}_{16: 0}$ & $33 \cdot 2$ & $29 \cdot 8$ & $25 \cdot 2$ \\
$\mathrm{C}_{17: 0}$ cyclo & $15 \cdot 9$ & $17 \cdot 1$ & $23 \cdot 6$ \\
$\mathrm{C}_{17: 0}$ & $1 \cdot 0$ & $1 \cdot 2$ & $1 \cdot 6$ \\
$\mathrm{C}_{18: 1} \omega 7 c$ & $9 \cdot 0$ & $13 \cdot 1$ & $13 \cdot 1$ \\
Summed feature $3 *$ & $29 \cdot 3$ & $23 \cdot 2$ & $21 \cdot 0$ \\
\hline
\end{tabular}

*Summed feature 3 comprised $\mathrm{C}_{15: 0}$ iso $2-\mathrm{OH}$ and/or $\mathrm{C}_{16: 1} \omega 7 \mathrm{c}$. 


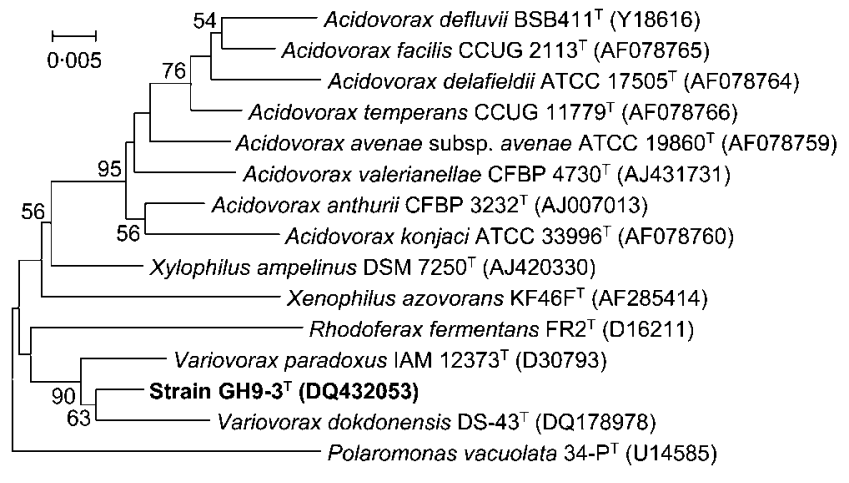

Fig. 1. Neighbour-joining phylogenetic tree based on $16 \mathrm{~S}$ rRNA gene sequences, showing the position of strain $\mathrm{GH} 9-3^{\top}$. Bootstrap values are shown as percentages of 1000 replicates. Only bootstrap values above $50 \%$ are shown. GenBank accession numbers are shown in parentheses. Bar, 0.5 nucleotide substitutions per 100 nt.

\section{Description of Variovorax soli sp. nov.}

Variovorax soli (so'li. L. neut. gen. n. soli of soil, the source of the organism).

Cells are Gram-negative, motile, non-spore-forming, short and rod-shaped $(0.5-0.7 \times 1 \cdot 0-1.5 \mu \mathrm{m})$. Colonies are irregular and light yellow in colour after 2 days on R2A. Able to grow between 10 and $35^{\circ} \mathrm{C}$ (optimal growth at $30{ }^{\circ} \mathrm{C}$ ) and at $\mathrm{pH} 5 \cdot 0-9 \cdot 0$ (optimal growth at $\mathrm{pH} 7 \cdot 0$ ). Tolerates up to $3 \% \mathrm{NaCl}$. Catalase- and oxidase-positive. Hydrolyses tyrosine and urea (prolonged incubation of over 2 weeks), but does not hydrolyse casein, carboxymethylcellulose or DNA. The major cellular fatty acids are $\mathrm{C}_{16: 0}$, summed feature 3, $\mathrm{C}_{17: 0}$ cyclo and $\mathrm{C}_{18: 1} \omega 7 \mathrm{c}$. Q-8 is the predominant isoprenoid quinone. The $\mathrm{G}+\mathrm{C}$ content is $67 \cdot 1 \mathrm{~mol} \%$.

The type strain, GH9- $3^{\mathrm{T}}\left(=\mathrm{KACC} 11579^{\mathrm{T}}=\mathrm{DSM} 18216^{\mathrm{T}}\right.$ ), was isolated from greenhouse soil cultivated with lettuce in Wanju region, Republic of Korea.

\section{Acknowledgements}

This study was supported by a programme of international co-research work between the Rural Development Administration (RDA), South Korea, and DSMZ, Germany.

\section{References}

Anzai, Y., Kim, H., Park, J.-Y., Wakabayashi, H. \& Oyaizu, H. (2000). Phylogenetic affiliation of the pseudomonads based on 16S rRNA sequence. Int J Syst Evol Microbiol 50, 1563-1589.

Groth, I., Schumann, P., Weiss, N., Martin, K. \& Rainey, F. A. (1996). Agrococcus jenensis gen. nov., sp. nov., a new genus of actinomycetes with diaminobutyric acid in the cell wall. Int J Syst Bacteriol 46, 234-239.

Kumar, S., Tamura, K. \& Nei, M. (2004). MEGA3: integrated software for molecular evolutionary genetics analysis and sequence alignment. Brief Bioinform 5, 150-163.

Kwon, S. W., Kim, J. S., Park, I. C., Yoon, S. H., Park, D. H., Lim, C. K. \& Go, S. J. (2003). Pseudomonas koreensis sp. nov., Pseudomonas umsongensis sp. nov. and Pseudomonas jinjuensis sp. nov., novel species from farm soils in Korea. Int J Syst Evol Microbiol 53, 21-27.

Mesbah, M., Premachandran, U. \& Whitman, W. B. (1989). Precise measurement of the $\mathrm{G}+\mathrm{C}$ content of deoxyribonucleic acid by highperformance liquid chromatography. Int J Syst Bacteriol 39, 159-167.

Reasoner, D. J. \& Geldreich, E. E. (1985). A new medium for the enumeration and subculture of bacteria from potable water. Appl Environ Microbiol 49, 1-7.

Sasser, M. (1990). Identification of bacteria by gas chromatography of cellular fatty acids. Technical Note no. 101. Newark, DE: MIDI Inc.

Seldin, L. \& Dubnau, D. (1985). Deoxyribonucleic acid homology among Bacillus polymyxa, Bacillus macerans, Bacillus azotofixans, and other nitrogen-fixing Bacillus strains. Int J Syst Bacteriol 35, 151-154.

Smibert, R. M. \& Krieg, N. R. (1994). Phenotypic characterization. In Methods for General and Molecular Bacteriology, pp. 607-654. Edited by P. Gerhardt, R. G. E. Murray, W. A. Wood \& N. R. Krieg. Washington, DC: American Society for Microbiology.

Stackebrandt, E. G. \& Goebel, B. M. (1994). Taxonomic note: a place for DNA-DNA reassociation and 16S rRNA sequence analysis in the present species definition in bacteriology. Int J Syst Bacteriol 44, 846-849.

Thompson, J. D., Higgins, D. G. \& Gibson, T. J. (1994). CLUSTAL W: improving the sensitivity of progressive multiple sequence alignment through sequence weighting, position-specific gap penalties and weight matrix choice. Nucleic Acids Res 22, 4673-4680.

Willems, A., De Ley, J., Gillis, M. \& Kersters, K. (1991). Comamonadaceae, a new family encompassing the acidovorans rRNA complex, including Variovorax paradoxus gen. nov., comb. nov., for Alcaligenes paradoxus (Davis 1969). Int J Syst Bacteriol 41, 445-450.

Yoon, J.-H., Kang, S.-J. \& Oh, T.-K. (2006). Variovorax dokdonensis sp. nov., isolated from soil. Int $J$ Syst Evol Microbiol 56, $811-814$. 